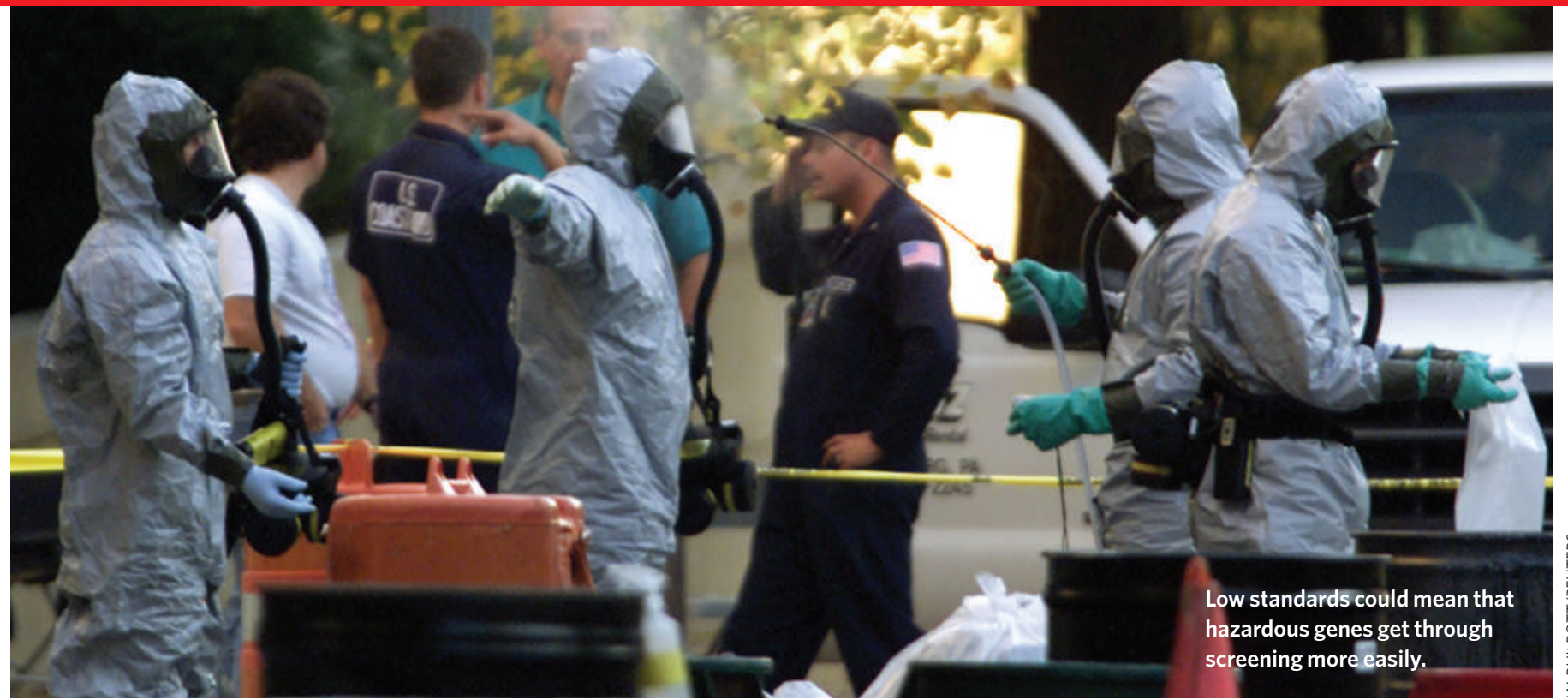

\title{
Keeping genes out of terrorists' hands
}

\section{Gene-synthesis industry at odds over how to screen DNA orders.}

A standards war is brewing in the gene-synthesis industry. At stake is the way that the industry screens orders for hazardous toxins and genes, such as pieces of deadly viruses and bacteria. Two competing groups of companies are now proposing different sets of screening standards, and the results could be crucial for global biosecurity.

"If you have a company that persists with a lower standard, you can drag the industry down to a lower level," says lawyer Stephen Maurer of the University of California, Berkeley, who is studying how the industry is developing responsible practices. "Now we have a standards war that is a race to the bottom."

For more than a year a European consortium of companies called the International Association of Synthetic Biology (IASB) based in Heidelberg, Germany, has been drawing up a code of conduct that includes gene-screening standards. Then, at a meeting in San Francisco last month, two of the leading companies - DNA2.0 of Menlo Park, California, and Geneart of Regensburg, Germany announced that they had for-

\section{"Now we have a standards war that is} a race to the bottom." mulated a code of conduct that differs in one key respect from the IASB recommendations.

Both codes involve an automated step, in which the genes in a customer's order are compared against those from organisms on lists such as the US Centers for Disease Control and Prevention's 'select agents' list. This step uses computer programs such as the US National Center for Biotechnology Information's Basic Local Alignment Search Tool (BLAST), which searches for similarities between gene sequences.

But although the IASB standard specifies that a human expert will follow up on possible 'hits' identified in the automated screening step, the DNA2.0/Geneart code ends with the automated screening step. The two firms are now merging their databases of genes of concern. This worries some observers, because it is difficult to translate the list of select-agent organisms into lists of dangerous genes (although a panel convened by the National Academy of Sciences is meeting in Washington DC on 3 September to grapple with this problem). And no one believes that such lists will catch every dangerous gene. For instance, they might not identify genes from harmless organisms that had been modified in some new and deadly way, so many companies use human expertise to review the results.

\section{Lowest common denominator}

But human expertise costs money, and competition is fierce in the gene-synthesis field, with roughly 50 dedicated companies fulfilling some 50,000 gene orders per year. And some observers think that the industry as a whole might now adopt the cheaper DNA 2.0/ Geneart standard. That concerns Markus Fischer, a member of the IASB board and a managing director of Entelechon of Regensburg.

"The proposal from DNA2.0 and Geneart is a kind of lowest-common-denominator idea," Fischer says. "Simply taking a list of genes, performing a BLAST against them and taking a sort of threshold cut-off and saying everything below that cut-off is not of interest to us is frankly a little bit naive and dangerous."

Claes Gustafsson, vice-president of sales and marketing for DNA2.0, counters that human screening is also not perfect. "There's no way to standardize it," he explains. And as for the incomplete nature of databases of select-agent genes, "we're just going to deal with the stuff that we know something about", he says. "How do you deal with the unknown? It's outside the scope of science."

He also says that discussions on governance of gene synthesis have been going on among policy experts and governments for many years, with no definitive conclusion. "We decided to standardize everything, make it consistent, and move on," he says.

Other companies have not yet decided where they stand on the issue. In November, the IASB will convene a meeting in Cambridge, Massachusetts, to discuss adopting its code of conduct. But already, some companies are intrigued by the DNA2.0/Geneart proposal.

"Our intention is to review the [DNA2.0/ Geneart] process and seriously consider switching to that," says John Mulligan, founder and chief scientific officer of Blue Heron Biotechnology, a gene-synthesis company in Bothell, Washington. His company might, however, still keep some of its manual scrutiny. "What I see may come out of this is a standardized minimum across the industry with some companies choosing to augment that," he says.

Maurer says he hopes that government officials in the United States, the country most concerned about biosecurity, will step in and communicate with industry about its preferred standard. So far, many branches of the government have been involved in working on potential regulations, but none has offered opinions on concrete issues such as screening standards.

"I think if the government expressed an opinion, DNA2.0 would blink," Maurer says. "A little bit of effort now would steer them towards the top of existing practice rather than near the bottom."

Erika Check Hayden 